\title{
ESTABLISHING A TEACHING PRACTICE PROCESS THROUGH TRAIN THE TRAINER PROGRAM IN THE SINABUNG VOLCANO'S EXCLUSION ZONE: A QUALITATIVE CASE STUDY IN MARDINGDING VILLAGE AT THE DISTRICT OF KARO
}

\author{
Choms Gary Ganda Tua Sibarani ${ }^{1 *}$, Andri Zainal ${ }^{1}$, Rini Herliani ${ }^{1}$ \\ ${ }^{1}$ Department of Accounting, Faculty of Economics, Universitas Negeri Medan, Medan, Indonesia \\ *Corresponding Author: gary.linacker@gmail.com
}

\begin{abstract}
This paper discusses the outcomes resulted from efforts in optimizing the implementation of a teaching practice process in a current/post-disaster area. The purpose of this study is to implement the Trainthe-Trainer program for local youth as educational agents to pupils in Mardingding Village and in other villages around those affected by the disaster so that the learning spirit of students is maintained. Based on the data analysis using the rapid mapping method with the Rapid Spiral Boehm model, it can be concluded that the implementation and existence of the Train the Trainer program has a positive influence on students' interest in learning activities that are not only focused on activities within the school but also outside the school. The relatively good achievement of learning outcomes after the implementation of the train the trainer program underscores interesting findings in which regions experiencing disasters can still meet learning outcomes with all the inherent limitations of the condition of the affected area. This applied research has limitations, namely focusing on qualitative data analysis so that the interpretation of the findings obtained also has relatively specific implications for the coverage of the Mardingding Village area in the Tiganderket District in Karo District.
\end{abstract}

Keywords: Train the Trainer Program, Teaching Practice Process, Disaster Area, Mardingding Village, Rapid Spiral Boehm.

\section{INTRODUCTION}

Indonesia is the country most prone to natural disasters according to the United Nations International Strategy of Disaster Education (UNISDR) due to natural factors in Indonesia. Indonesia stands at the confluence of 3 large tectonic plates, namely the Indo Australia plate, Eurasia, and the Pacific plate. Around the location of the meeting of these plates accumulated energy collisions and collected until a point of the earth's layer is no longer able to withstand a pile of energy so that it occurs in the form of earthquakes and volcanic eruptions.

Mount Sinabung in North Sumatra is one of the volcanoes in Indonesia, which until now the eruption has not been detected when it stopped. As a result of the eruption, many residents from various villages were evacuated for fear of being affected by the eruption of Mount Sinabung. Mardingding village is one of the worst affected villages within 3 $\mathrm{km}$ of the peak of the crater of Mount Sinabung (source: http://news.liputan6.com/read/803888/video-debu-vulkaniksinabung-kian-tebal-warga- displaced). Many facilities cannot be used anymore because of volcanic ash and broken road access due to cold lava. Since the eruption of Mount Sinabung, the majority of community activities ranging from agriculture, livestock farming to trade are no longer running as usual.

As a result of the eruption of Mount Sinabung, the people of Mardingding Village had to be evacuated to a sheltered post located in Kampung Trong Peren Gudang Konco in Tiganderket Subdistrict with a population of approximately 934 people consisting of 265 households. A total of 108 tents were allocated to refugee camps for temporary shelter (source: based on the results of interviews with the Mardingding Village Chief, Ms. Minarti Br. Sembiring). The community that initially had a livelihood as a farmer is now turning professions as call laborers because of damaged agricultural land hit by cold lava.

In particular, in the field of education, many facilities cannot be used anymore including school buildings because the roof is leaking due to the thick volcanic ash that overloads the protective parts of the building and covers the school area. In addition, the cold lava flow has cut off access to the school. As a result, educational activities ranging from basic education to follow-up held in Mardingding Village no longer run effectively and efficiently. Student learning activities become ineffective in the evacuation because the situation and environment are not conducive which causes 
student learning interest to decline. This condition is exacerbated by the situation where students in the evacuation post now have to go to another school located in Jandi Meriah Village, which is about $2 \mathrm{KM}$ from the location of the post. Based on information from the community in the evacuation post, the school only had three large rooms partitioned with tarpaulin into two rooms. Thus, the total number of rooms becomes 6 rooms for classes 1, 2, 3, 4, 5, and 6. Every day two transport trucks are provided to pick up the students, amounting to 116 people with subsidies from the Government which has not been received since the beginning of 2016 by the owner of the transportation service. This also influences the efficiency and effectiveness of the learning process for students in the evacuation post so that it becomes the basis for us to conduct further research to overcome the various problems described earlier.

This study is motivated by similar activities that have been carried out in the village of Solukhumbu, the North Hills region in Nepal (source: http://www.emboldenalliances.org/using-local-networks-and-supporting education-indisaster-relief /) were through the train-the-trainer program for the community in the earthquake disaster area, it has been able to optimize the implementation of education in post-disaster areas. Technically, overcoming the problem of organizing basic education for students at the location of the Mardingding Village evacuation post will be described in the next section.

This paper is intended to provide preliminary information about the potential of relevant local human resources to be involved in the Train-the-Trainer program, which is, of course, adapted to the needs of people affected by the eruption of Mount Sinabung in Mardingding Village, Karo District. This information will be useful for the development of partnerships that can show local capabilities related to the sustainability of educational activities in disaster areas.

As explained in the Ramalingam and Sanderson (2015) report that humanitarian response by strengthening the local capacity of people affected by the crisis is better prepared, more resilient in facing risks as a result of disasters. Furthermore, investment in local partnerships can build resilience and reduce disaster risk and on the other hand, can improve local quality so that it can accelerate the recovery process of disaster areas. In addition, sustainability during a disaster is very important to note, this is expected to be prepared by local human resources to ensure sustainable education in disaster areas as appropriate.

The Train-the-Trainer program theoretically contributes to improving education in disaster areas. The implementation of Train-the-Trainer uses the role-playing method. The method of role-playing as one of the learning methods chosen in the teaching and learning process in the classroom is believed to be able to become the main attraction for students (Kartini, 2007). In addition, the author asserted that students are very enthusiastic or very attentive to the lesson when the lesson is indeed concerning his daily life in the community. while the role-playing method is very focused on the realities that occur in the community that are delivered by teaching staff in the local area that has been known by students. Therefore, the Train-the-Trainer program is very important to implement. In the condition of the disaster area which is limited by educators (teachers), it is expected that the Train-the-Trainer program is able to transfer the knowledge of education to local communities who have a good educational background.

\section{IMPLEMENTATION METHOD}

The research location was selected purposively in Mardingding Village, Tiganderket Subdistrict, Karo Regency, North Sumatra Province with the consideration that the area was one of the disaster areas of Mount Sinabung and most students did not continue their education. Furthermore, the type of data used in this study is primary data obtained from direct observation, enumeration, and interviews with the Village Chief of Mardingding, the community and children in the refugee camp. Primary data obtained by interviews to obtain information related to the profile of students, learning of existing students in refugee camps, and the application of the Train-the-Trainer program in disaster areas. Data on the findings of subsequent research are compared with various previous literature related to these findings.

Related to the process of data collection is carried out by survey methods assisted by structured instruments. Data collection techniques are observation, interview, and documentation techniques. Observation techniques carried out by direct observation in the village of Mardingding to find out the educational problems in the area. The data carried out through direct interviews with the Mardingding Village Chief, the community and children in refugee camps aims to build the spirit of student learning with the restoration of education in Mardingding Village, forming a Train-theTrainer community especially for basic education and providing training guidance to young people who do not continue to higher education by developing existing skills to advance the economy. While for the preparation of learning modules in accordance with the study of literature. The variables observed in this study were the location of refugee areas, education, work experience, adolescents (youth community), people's lives, and students.

Data that has been collected is then analyzed to produce interpretations related to scientific studies. The data analysis technique used is qualitative data analysis. Qualitative data analysis was obtained from collected data processed and analyzed according to the problem, namely identifying the number of people having potential, community involvement in the Train-the-Trainer program, teenage graduates in refugee camps and work experience. The rapid 
mapping method emphasizes the applied action of the Train-the-Trainer program by analyzing qualitative data that considers regional conditions. Rapid used is Rapid Spiral Boehm (RSB) which aims to answer certain problems during the research process.

\section{RESULTS AND DISCUSSION}

\subsection{General Description of The Community}

The target area is Mardingding Village, Tiganderket District, Karo Regency. The distance of the Mardingding village to the mountain crater ranges from $3 \mathrm{Km}$. This is what has caused this village to become one of the villages displaced from 9 refugee points due to the eruption of Mount Merapi. They were evacuated to other areas, namely the Tron Peren Gudang Konco post in Tiganderket District. The location of the evacuation is on the edge of the road and is quite far from the village of Mardingding itself. This village has a population of approximately 934 people consisting of 265 family heads (KK). The educational background of the people of Mardingding Village is mostly junior high school graduates, but many also graduate high school to tertiary level.

\subsection{Research Results and Discussion}

Based on research conducted on 25 respondents in the Tron Peren Gudang Konco evacuation post, Tiganderket Subdistrict which was analyzed qualitatively using the rapid mapping method and RSB model to prove the hypothesis proposed by the researcher. The variable studied was the condition of children's education. When interviewing respondents. Respondent is accompanied by the researcher if there is something less clear from the statements of the research team. The research was carried out for 3 days and assisted by 2 local residents who understood the problems related to conducting research. During the implementation of the research in the field the research team managed to conduct discussions and interviews of 9 people/day. In general, the interview process for respondents takes 10 minutes.

In detail based on qualitative data analysis using the two methods described in the following table:

Table 1. Identification of Problems.

\begin{tabular}{|l|l|l|}
\hline \multicolumn{1}{|c|}{ Method / Model } & \multicolumn{1}{|c|}{ Problem } & \multicolumn{1}{c|}{ Findings } \\
\hline Fast Mapping & $\begin{array}{l}\text { 1. Inadequate learning facilities } \\
\text { 2. Educators are limited } \\
\text { 3. The learning atmosphere is not } \\
\text { conducive }\end{array}$ & $\begin{array}{l}\text { 1. The teaching and learning } \\
\text { process takes place with natural } \\
\text { schools } \\
\text { 2ore diverse educators in the } \\
\text { teaching and learning process } \\
\text { can take place outside of school. } \\
\text { There are 4 educators who have } \\
\text { teaching hours ranging from 5 } \\
\text { hours/day. } \\
\text { The atmosphere of the teaching } \\
\text { and learning process is not } \\
\text { monotonous and varied }\end{array}$ \\
\hline Rapid Spiral Boehm & $\begin{array}{l}\text { No teaching and learning activities } \\
\text { have been carried out at the } \\
\text { location of the disaster post. }\end{array}$ & $\begin{array}{l}\text { The implementation of the Train- } \\
\text { the-Trainer program at the location } \\
\text { of the disaster post. }\end{array}$ \\
\hline
\end{tabular}

Can be concluded through the analysis described in the table above. In general, the effectiveness of the Train-theTrainer program shows significant results as described in the following table:

Table 2. Results of Study.

\begin{tabular}{|l|l|l|l|}
\hline No. & \multicolumn{1}{|c|}{ Indicator } & \multicolumn{1}{c|}{ Pre-Study } & \multicolumn{1}{c|}{ Post-Study } \\
\hline 1. & Learning Community & $\begin{array}{l}\text { The learning community has } \\
\text { not yet been formed. }\end{array}$ & $\begin{array}{l}\text { Community: The formation of a learning } \\
\text { community in refugee camps through the } \\
\text { Train-the-Trainer program for communities } \\
\text { in the villages of Mardinding and in other } \\
\text { villages. }\end{array}$ \\
\hline
\end{tabular}




\begin{tabular}{|l|l|l|l|}
\hline 2. & Knowledge transfer & $\begin{array}{l}\text { Knowledge and public } \\
\text { awareness of education are } \\
\text { still very small. And do not } \\
\text { have the skills to educate and } \\
\text { teach as a substitute for the } \\
\text { role of the teacher. Learning } \\
\text { activities are still in school. }\end{array}$ & $\begin{array}{l}\text { Transfer of knowledge: the community gets a } \\
\text { lot of knowledge to educate and teach that has } \\
\text { been gained in Train-the-Trainer training. } \\
\text { Namely: understanding more about the latest } \\
\text { education and increasing awareness of the } \\
\text { importance of education at this time. } \\
\text { Learning activities are not only done at } \\
\text { school but learning has been done outside the } \\
\text { school such as in the refugee camp. }\end{array}$ \\
\hline 3. & Partnership & $\begin{array}{l}\text { There is no partnership } \\
\text { between Mardinding Village } \\
\text { and other parties, especially } \\
\text { educational institutions. }\end{array}$ & $\begin{array}{l}\text { Partnership: a partnership program has been } \\
\text { established between the Mardinding Village } \\
\text { Community and Medan State University. } \\
\text { And it is expected that in the following year } \\
\text { there will be cooperation with the } \\
\text { Government and the private sector. }\end{array}$ \\
\hline
\end{tabular}

\section{CONCLUSION}

The purpose of this study is to implement the Train-the-Trainer program in Mardingding Village and in other villages to build spirit student learning. Based on data analysis using fast mapping method and rapid spiral Boehm model, it can be concluded that the positive influence of the existence of the Train-the-Trainer program on student interest in learning activities is not only focused on activities at school but outside of school. And evaluate before and after the implementation of the Train-the-Trainer program. This provides an interesting finding where regions experiencing disasters can still carry out the teaching and learning process with all the limitations that are not only done in schools.

In the future, it is expected that the Train-the-Trainer program can be more socialized to disaster areas, so that not only in Mardingding village but in other villages. After the implementation of teaching and learning facilities outside of school education (natural schools), it can improve the quality of education in the local area. This study has limitations, namely focusing on qualitative data analysis, then the next study is expected to use quantitative data analysis by evaluating the implementation of the Train-the-Trainer program that uses experimental research to contribute.

\section{REFERENCE}

Kartini, T. (2007). Penggunaan Metode Role Playing untuk Meningkatkan Minat Siswa dalam Pembelajaran Pengetahuan Sosial di Kelas V SDN Cileunyi I Kecamatan Cileunyi Kabupaten Bandung. Jurnal Pendidikan Dasar, 8, 1-5.

Ramalingam, B. \& Sanderson, D. Nepal earthquake response: Lessons for operational agencies. ALNAP Report. ALNAP lessons paper. London: ALNAP/ODI;2015. http://reliefweb.int/sites/reliefweb.int/files/resources/nepal-earthquake-response-lessonspaper.pdf.

Tersedia dari: http://www.alnap.org/resource/20123 